\title{
VARIABEL KEUANGAN YANG MEMBEDAKAN TINGKAT LIKUIDITAS BANK UMUM DI BURSA EFEK INDONESIA
}

\author{
A.A.Ayu Diah Ambarawati ${ }^{1}$ \\ I Gusti Bagus Wiksuana ${ }^{2}$ \\ Luh Gede Sri Artini ${ }^{3}$ \\ ${ }^{1}$ Fakultas Ekonomi dan Bisnis Universitas Udayana, Bali, Indonesia \\ Email: dh.ambar@yahoo.com \\ ${ }^{2}$ Fakultas Ekonomi dan Bisnis Universitas Udayana, Bali, Indonesia \\ ${ }^{3}$ Fakultas Ekonomi dan Bisnis Universitas Udayana, Bali, Indonesia
}

\begin{abstract}
ABSTRAK
Penelitian ini mengembangkan suatu model penelitian yang bertujuan untuk menjelaskan rasiokeuangan yang dapat membedakan tingkat likuiditas bank umum, serta mengidentifikasi rasio keuangan mana diantara rasio keuangan yang membedakan tersebut paling dominan membedakan tingkat likuiditas bank yang terdaftar di BEI periode 20102014. Variabel independen dalam penelitian adalah rasio keuangan bank yaitu ukuran bank, NWC, CAR, ROA, ROE dan NPL.Variabel dependen yang digunakan dalam penelitian ini adalah rasio likuiditas dengan indikator Loan to Deposit Ratio (LDR).Analisis data dalam penelitian ini menggunakan teknik analisis diskriminan. Berdasarkan uji diskriminan dengan metode simultancemenyatakan bahwa model diskriminan Unstandardized Canonical Discriminant Function (UCDF) dapat mengklasifikasikan dua kelompok bank umum berdasarkan nilai diskriminannya dengan tepat sebesar $69,2 \%$ dari total sampel atau terjadi kesalahan klasifikasi sebesar $30,8 \%$. Hasil penelitian menunjukkandari keenam variabel independen dalam penelitian ini, hanya 3(tiga) variabel yangmemiliki nilai signifikansi $<0,1$ sehingga dapat membedakan tingkat likuiditas bank umum. Variabel yang dapat membedakan tingkat likuiditas bank umum tersebut adalah CAR (sig=0,061), NPL (sig=0,067) serta NWC (sig=0,074). Variabel CAR dengan nilai signifikansi paling rendah menunjukan variabel tersebut paling dominan membedakan tingkat likuiditas bank umum yang terdaftar BEI.
\end{abstract}

Kata Kunci :ukuran bank, NWC, CAR, ROA, ROE dan NPL.

\begin{abstract}
This research developed a research model that aims to explain financial ratio that can differentiate the liquidity level of commercial banks, and identify the financial ratios which among the financial ratios that sever the most dominant to sever the liquidity level of banks listed on the IDX period 2010-2014. The independent variables in the research are bank financial ratios of bank size, NWC, CAR, ROA, ROE and NPL. Dependent variable used in this research is liquidity ratio with Loan to Deposit Ratio (LDR) indicator. The data analysis in this research uses discriminant analysis technique. Based on discriminant test with simultaneous method, the discriminant model of Unstandardized Canonical Discriminant Function (UCDF) can classify two groups of commercial banks based on their discriminant value by exactly $69.2 \%$ of the total sample or classification error of $30,8 \%$. The result of research indicate from the six independent variables in this research, only 3 (three) variables have significance value <0,1 so it can sever liquidity level of commercial bank. Variables that can differentiate the liquidity level of the commercial banks are CAR (sig =0.061), NPL (sig = 0.067) and NWC (sig =0.074). CAR variable with the lowest significance value shows that the most dominant variable sever the liquidity level of commercial banks listed BEI.
\end{abstract} Keywords: bank size, NWC, CAR, ROA, ROE and NPL. 


\section{PENDAHULUAN}

Bank dengan perannya sebagai lembaga intermediasi yaitu menerima dan menyalurkan dana masyarakat, harus menjaga likuiditasnya dengan baik. Taswan (2011) menyebutkan likuiditas bank adalah kemampuan bank untuk memenuhi kemungkinan ditariknya deposito atau simpanan oleh deposan atau penitip dana atau memenuhi kebutuhan masyarakat berupa kredit. Bank tidak dapat menjual kreditnya dengan harga tinggi dengan cepat sedangkan di satu sisi penyimpan dana dapat sewaktu-waktu menarik dananya, sehingga kewajiban bank lebih likuid dari asset bank (Diamond, 2007),dengan kata lain, suatu bank dapat dikatakan likuid apabila bank yang bersangkutan tersebut dapat membayar semua hutang-hutangnya terutama simpanan giro, tabungan dan deposito pada saat ditagih oleh para nasabah penyimpan dana serta dapat pula memenuhi semua permohonan kredit dari calon debitur yang layak untuk dibiayai.Oleh karena itu bank harus menjaga likuiditasnya guna memastikan sewaktu-waktu dapat memenuhi kewajiban jangka pendeknya.

Krisis likuiditas pernah terjadi pada perbankan Indonesia pada tahun 2008, dimana pada saat itu terjadi aliran dana keluar (capital outflow) secara besarbesaran dan menurunnya kualitas asset perbankan. Situasi krisis saat itu juga berimbas pada bank-bank skala besar dimana pada Oktober 2008, ada tiga bank besar BUMN yakni PT Mandiri, Tbk, PT BNI, Tbk dan PT BRI, Tbk mendapat bantuan likuiditas dari pemerintah masing-masing sebesar Rp 5 M. Bantuan likuiditas ini menyebabkan bank-bank umum lainnya makin terpuruk, dana simpanan masyarakat pindah ke bank-bank besar tersebut atau ke luar negeri. 
(Bank Indonesia, 2010).Belajar dari historis, krisis perbankan yang terjadi selama ini terutama disebabkan oleh krisis likuiditas bank yang menyebabkan terjadinya gagal bayar bank terhadap sebagian besar kewajibannya (Gantiah et al, 2014).Kegagalan bank dalam menjalankan perannya sebagai lembaga intermediasi yaitu menerima dan menyalurkan dana masyarakat dapat berdampak sistemik, mengingat adanya keterkaitan bank dengan bank lainnya baik secara langsung maupun tidak langsung.

Masalah likuiditas akan mempengaruhi laba dan modal bank, pengelolaan risiko likuiditas bank yang baik dapat menghindari bank dari penjualan asset secara besar-besaran (Ahmed, 2012). Risiko likuiditas tidak hanya mempengaruhi kinerja bank tapi juga reputasi bank (Jenkinson, 2008). Sebuah bank yang tidak dapat memberikan dana deposannya tepat waktu akan kehilangan kepercayaan deposannya, dan pada saat itu reputasi bank akan dipertaruhkan. Goodhart (2008) menyatakan bank yang tidak likuid lebih cepat menjadi bangkrut.Hilman (2014) meneliti kebangkrutan perbankan di Indonesia berdasarkan risiko financial salah satunya adalah risiko likuiditas. Hasil penelitiannya mengemukakan Loan to Deposit Ratio (LDR), Current Asset to Total Deposits (CAD) dan Core Deposits to Total Liabilities (CDL) sebagai indikator rasio likuiditas berpengaruh signifikan terhadap kebangkrutan bank umum di Indonesia. Ahmed (2012) meneliti Deposits, cash, Non Performing Loans dan liquidity gap sebagai indikator risiko likuiditas terhadap pendapatan bank, dimana cash, NPL dan liquidity gap menurunkan tingkat pendapatan bank, sedangkan deposito meningkatkan pendapatan bank. 
PBI no.11/25/PBI/2009 mengidentifikasi 8 (delapan) risiko yang harus dikelola bank, salah satu diantaranya adalah risiko likuiditas.Risiko likuiditas menurut PBI no.13/1/PBI/2011 adalah risiko akibat ketidakmampuan Bank untuk memenuhi kewajiban yang jatuh tempo dari sumber pendanaan arus kas, dan/atau dari asset likuid berkualitas tinggi yang dapat diagunkan, tanpa mengganggu aktivitas dan kondisi keuangan bank.Bank Indonesia melalui Surat Edaran Bank Indonesia nomor. 13/24/DPNP tanggal 25 Oktober 2011, mengukur risiko likuiditas melalui rasio Loan to Deposit Ratio (LDR) yang menggambarkan kemampuan suatu bank membayar kembali penarikan yang dilakukan nasabah dengan mengandalkan kredit yang diberikan sebagai sumber likuiditas Dendawijaya (2009). Semakin tinggi rasio LDR suatu bank menunjukan bank memberikan pinjaman seluruh dananya (loan up) atau relatif tidak likuid (illiquid) (Latumaerissa , 2014).

Bank yang memiliki rasio LDR yang rendah menunjukan bank tersebut memiliki tingkat likuiditas yang tinggi. Namun apabila tingkat likuiditas bank terlalu tinggi, menunjukan bank memiliki dana yang besar sehingga berpotensi dana idle dan memperbesar cost of fundyang nantinya berpengaruh pada menurunnya pendapatan bank. Sebaliknya bank yang memiliki rasio LDR yang tinggi menunjukan bank tersebut memiliki tingkat likuiditas yang rendah. Rasio LDR yang tinggi menunjukan kredit yang diberikan bank tinggi dan bank akan menerima peningkatan pendapatan dari kredit yang disalurkan tersebut. Namun semakin tinggi kredit yang diberikan potensi bank terekspose risiko kredit atau gagal bayar juga semakin tinggi. Disamping itu rasio LDR yang tinggi justru 
membuat bank dapat mengalami kesulitan likuiditas.Oleh karena itu bank perlu mengelola likuiditasnya dengan baik, tidak terlalu rendah dan tidak terlalu tinggi. Untuk menjaga kesehatan bank, Bank Indonesia melalui Peraturan Bank Indonesia Nomor 15/7/PBI/2013 menetapkan besar LDR pada kisaran 78\%-92\%.

Bank-bank yang terdaftar di Bursa Efek Indonesia (BEI) harus menunjukan kinerja yang baik agar menarik bagi investor, termasuk pengelolaan likuiditas yang ditunjukan dari rasio LDR.Periode 2010-2014 terdapat 26 bank umum yang terdaftar di BEI.

Variabel yang mempengaruhi likuiditas bank, baik pada bank umum konvensional maupun bank syariah telah diteliti dalam penelitian sebelumnya. Rasio - rasio atau indikator risiko likuiditas dalam penelitian Arif (2013) terdiri dari ukuran bank, Net Working Capital (NWC), Return on Asset (ROA), Capital Adequacy Ratio (CAR), Return on Equity (ROE), Non Performing Loan (NPL), suku bunga deposito dan suku bunga kredit, dimana ukuran bank, Net Working Capital, ROA dan CAR berpengaruh positif terhadap likuiditas bank sedangkan ROE, NPL, Suku Bunga Deposito, suku bunga kredit berpengaruh negatif terhadap risiko likuiditas bank. Vodova (2010) dalam penelitiannya menggunakan variabel antara lainNon Performing Loan (NPL), Return on Asset (ROE) dan ukuran bank, dimana dalam penelitiannya menghasilkan variabel ukuran bank dan NPL berpengaruh positif terhadap likuiditas sedangkan ROE berpengaruh negatif terhadap likuiditas. Pengaruh positif NPL berbeda dengan hasil penelitian Arif (2013) yang menghasilkan variabel NPL berpengaruh negatif terhadap likuiditas bank. Akhtar et al (2011) dalam penelitian pada bank syariah dan konvensional di 
Pakistan menghasilkan ukuran bank dan Net Working Capital (NWC) memiliki hubungan positif dengan risiko likuiditas di kedua bank, sedangkan Capital Adequacy Ratio (CAR) berhubungan positif dengan risiko likuiditas pada bank konvensional, Return on Asset (ROA) berhubungan positif dengan risiko likuiditas pada bank syariah sedangkan Return on Equity (ROE) berhubungan negatif tidak signifikan pada bank konvensional dan signifikan pada bank syariah.

Ogilo et al (2015) dalam penelitian pada bank komersial di Kenya dengan variabel CAR, ukuran bank, Liquid Asset Ratio(LAR), ownership type dan laverage ratio menghasilkan variabel CAR memiliki pengaruh positif signifikan terhadap risiko likuiditas sedangkan variabel lainnya berpengaruh negatif. Hasil penelitian-penelitian sebelumnya hanya menganalisis signifikansi pengaruh dari rasio-rasio keuangan bank terhadap likuiditas bank namun belum menganalisa rasio-rasio yang dominan membedakan kelompok bank dengan rasio likuiditas diatas rata-rata dan kelompok bank dengan rasio likuiditas dibawah rata-rata bank umum, sedangkan penelitian ini meneliti rasio-rasio keuangan yang dominan membedakan tingkat rasio likuiditas bank umum yang terdaftar di BEI periode 2010-2014 menggunakan teknik analisis diskriminan. Variabel yang menjadi indikator likuiditas dalam penelitian ini adalah rasio - rasio neraca yang menunjukan likuiditas bank yaitu ukuran asset, Net Working Capital (NWC), Return on Asset (ROA), Capital Adequecy Ratio (CAR), Return on Asset (ROE), dan Non Perfoming Loans (NPL) yang telah diteliti dalam penelitian sebelumnya sebagai variabel risiko likuiditas. 
Berdasarkan teori dan penelitian-penelitian sebelumnya hipotesis dalam penelitian ini adalah sebagai berikut :

H1 : Rasio ukuran bank, Net Working Capital (NWC), Capital Adequecy Ratio (CAR), Return on Asset (ROA), Return on Equity (ROE) dan Non Performing Loan (NPL) diantaranya dapat membedakan tingkat rasio likuiditas bank.

H2 : Diantara rasio ukuran bank, Net Working Capital (NWC), Capital Adequecy Ratio (CAR), Return on Asset (ROA), Return on Equity (ROE) dan Non Performing Loan (NPL) terdapat rasio yang dominan membedakan tingkat rasio likuiditas bank.

Kerangka konseptual mengenai rasio-rasio keuangan yang diprediksi dapat membedakan rasio likuiditas bank yang disajikan pada gambar berikut : 


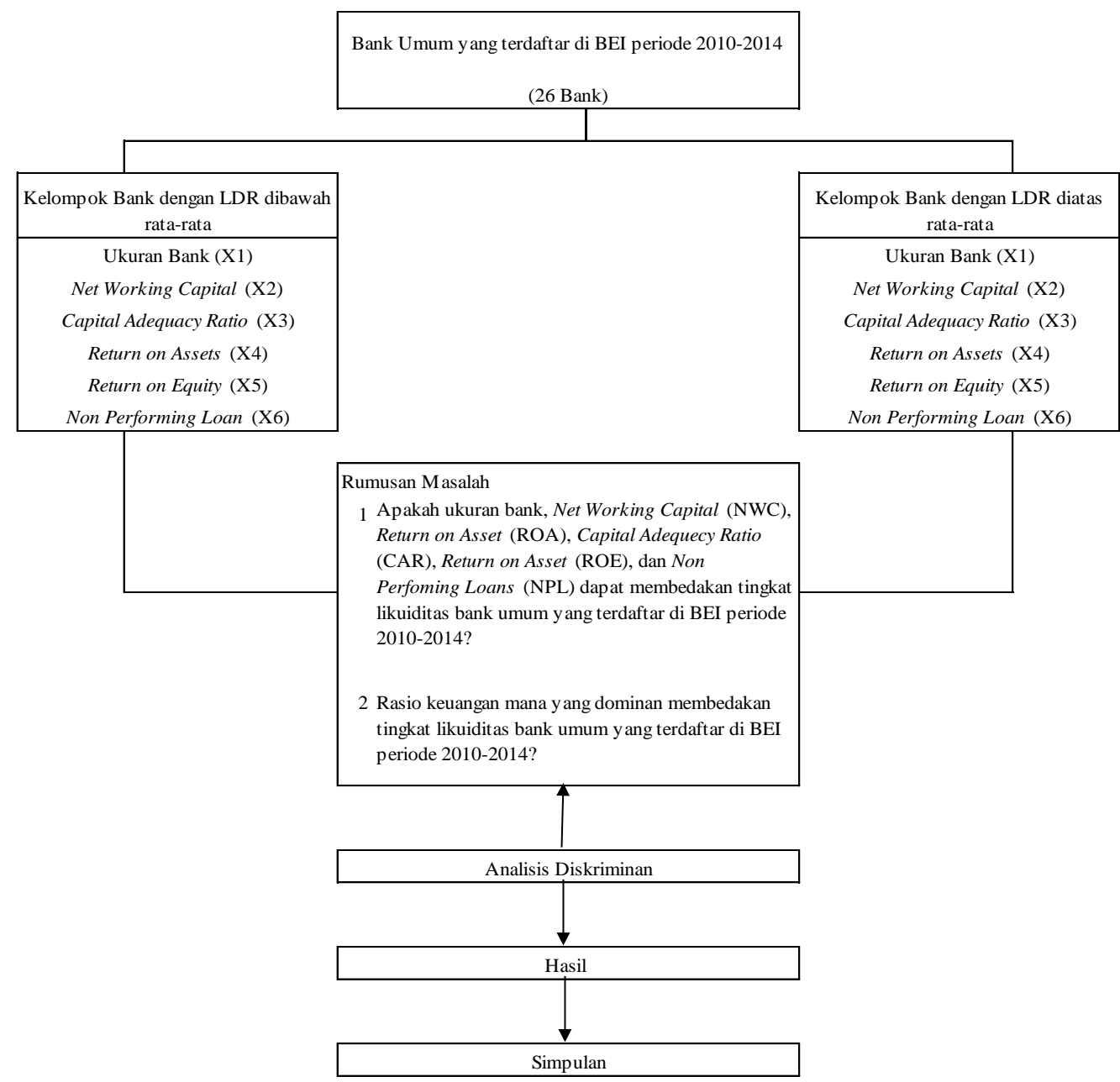

Gambar 1.Kerangka Konseptual Penelitian

\section{METODE PENELITIAN}

Penelitian ini menguji secara empirisrancangan dua hipotesis dengan menggunakan data-data kinerja keuangan bank umum yang terdaftar di bursa Efek Indonesia (BEI) periode tahun 2010-2014. Penelitian akan mengembangkan suatu model penelitian yang bertujuan untuk menjelaskan variabel - variabel yang dapat membedakan tingkat likuiditas bank umum, serta mengidentifikasi rasio keuangan mana dari yang paling dominan membedakan tingkat likuiditas bank. 
Variabel-variabel yang digunakan dalam penelitian ini antara lain :

1) Variabel Independen

Variabel independen independen dalam penelitian adalah variabel-variabel rasio likuiditas yaitu ukuran bank, NWC, CAR, ROA, ROE dan NPL.

2) Variabel Dependen

Variabel dependen yang digunakan dalam penelitian ini adalah rasio likuiditas dengan indikator Loan to Deposit Ratio (LDR).Penelitian ini menggunakan dummy variabel 1 dan 2 untuk merepresentasikan 2 kelompok bank yaitu kelompok bank dengan LDR diatas rata-rata dan kelompok bank dengan LDR dibawah rata-rata.Penentuan kelompok bank ini, didasarkan pada besar kecilnya rata-rata LDR bank, sehingga diperoleh nilai cut-off ratarata LDR bank sebesar 83,91\%. Nilai cut-offini untuk menentukan kelompok bank dengan rata-rata $\mathrm{LDR}$, dengan rincian sebagai berikut :

a) Angka 1 merepresentasikan bank yang memiliki rata-rata LDR diatas rata-rata LDR bank umum yang terdaftar di BEI selama periode 20102014. Kelompok Bank umum yang terdaftar di BEI dengan rata-rata LDR diatas cut-off( $>83,91)$, yaitu terdiri dari 13 bank umum.

b) Angka 2 merepresentasikan merepresentasikan bank yang memiliki rata-rata LDR dibawah rata-rata LDR bank umum yang terdaftar di BEI selama periode 2010-2014. Kelompok bank umum yang terdaftar di BEI dengan rata-rata LDR di bawah nilai cut-off $(<83,91)$, yaitu terdiri dari 13 bank umum. 


\section{Definisi Operasional Variabel}

Definisi operasional variabel-variabel dalam penelitian ini adalah sebagai berikut:

1) Ukuran bank

Ukuran bank dalam penelitian ini dilihat dari besarnya logaritma dari total asset.Total asset bank dilihat dari neraca masing-masing yang dipublikasikan.Penentuan nilai ukuran bank dalam penelitian ini dilakukan dengan menggunakan rumus sebagai berikut :

Ukuran Perusahaan $($ Size $)=$ LnTotalAktiva

Satuan ukuran bank dinyatakan dalam rupiah.

2) Net Working Capital (NWC)

NWC ini merupakan kekuatan intern untuk menggerakan kegiatan bisnis yaitu untuk membiayai kegiatan operasi rutin dan untuk membayar semua utang yang jatuh tempo. Rasio NWC merupakan selisih antara aktiva lancar dengan utang lancar dibandingkan dengan total asset bank. Penghitungan NWC menggunakan satuan persentase dengan rumus :

$$
\mathrm{NWC}=\text { Aset lancar }- \text { Utang lancar } \times 100 \%
$$

Total AsetCash Ratio (CR)

\section{3) Capital Adequecy Ratio (CAR)}

CAR merupakan rasio kecukupan modal yang dimiliki bank.Semakin tinggi rasio CAR bank semakin baik kemampuan bank tersebut untuk menanggung risiko dari setiap kredit/aktiva produktif yang berisiko.Penghitungan CAR dengan satuan persentase menggunakan rumus : 


$$
\mathrm{CAR}=\text { Modal } \times 100 \%
$$

\section{ATMR}

\section{4) Return on Equity (ROE)}

ROE merupakan rasio yang digunakan untuk mengukur laba bersih setelah pajak dengan modal sendiri.Rasio ini menunjukan tingkat efisiensi bank menggunakan modal sendiri yang dimiliki.Semakin tinggi rasio ini menunjukan posisi bank semakin kuat.Satuan data yang digunakan adalah persentase dan ROE dihitung dengan rumus sebagai berikut :

$$
\text { ROE }=\text { Laba Setelah Pajak } \quad x 100 \%
$$

Modal

\section{5) Return on Asset (ROA)}

ROA merupakan rasio untuk mengukur kemampuan bank dalam menghasilkan laba (keuntungan) secara keseluruhan.Semakin besar rasio ROA menunjukkan semakin besar pula tingkat keuntungan yang dicapai bank dan menunjukan semakin baik pula posisi bank.Satuan data yang digunakan adalah persentase dan ROA dihitung dengan rumus sebagai berikut :

$$
\text { ROA = Laba sebelum pajak dalam } 12 \text { bulan terakhir } \quad \text { x 100\% ...6) }
$$

Rata-Rata Volume Usaha dalam Periode yang Sama

6) Non Performing Loan (NPL)

NPL didefinisikan sebagai rasio yang menunjukan kredit bermasalah pada suatu bank.Semakin tinggi rasio NPL maka tingkat likuiditas bank terhadap 
dana pihak ketiga (DPK) akan semakin rendah.Rasio NPL yang digunakan adalah rasio NPL Net masing-masing bank.

NPL dihitung dengan satuan persentase menggunakan rumus sebagai berikut :

$\mathrm{NPL}=\underline{\text { Kredit Bermasalah }} \times 100 \%$ Kredit yang diberikan

Populasi dalam penelitian ini yaitu 26 bank umum yang terdaftar di Bursa Efek Indonesia (BEI) selama periode 2010-2014 yang seluruhnya digunakan sebagai sampel.Metode analisis data menggunakan analisis diskriminan dengan metode simultancous estimation.Mengacu peneltian Hair et al (1998)fungsi diskriminan menggunakan formula sebagai berikut:

$\mathrm{Z}=\mathrm{a}+\mathrm{W}_{1} \mathrm{X} 1+\mathrm{W}_{2} \mathrm{X} 2+\mathrm{W}_{3} \mathrm{X} 3+\mathrm{W}_{4} \mathrm{X} 4+\mathrm{W}_{5} \mathrm{X} 5+\mathrm{W}_{6} \mathrm{X} 6$

Keterangan :

1) $Z$ merupakan skor pada fungsi diskriminan yang menunjukkan tingkat rasio LDR bank umum yang terdaftar di BEI periode 2010-2014. Nilai cut-off untuk menentukan kelompok bank dengan rata-rata LDR diatas rata-rata dan dibawah rata-rata LDR bank umum yang terdaftar di BEI periode 2010-2014 yaitu sebesar 83,91, dengan pengelompokan sebagai berikut :

a) Angka 1 merepresentasikan kelompok bank umum yang terdaftar di BEI periode 2010-2014 yang memiliki rata-rata LDR di atas nilai cut-off ( $>83,91)$.

b) Angka 2 merepresentasikan kelompok bank umum yang terdaftar di BEI periode 2010-2014 yang memiliki rata-rata LDR di bawah nilai cut-off $(<83,91)$.

2) amerupakan intercept

3) $\mathrm{W}_{1}, \mathrm{~W}_{2}, \mathrm{~W}_{3}, \mathrm{~W}_{4}, \mathrm{~W}_{5}, \mathrm{~W}_{6}$, menunjukkan koefisien fungsi diskriminan dari masing-masing variabel untuk mengetahui apakah 6 (enam) variabel independen yang digunakan dalam penelitian ini secara nyata membedakan tingkat rasio $\mathrm{LDR}$

4) $X 1, X 2, X 3, X 4, X 5, X 6$ menunjukkan variabel independen yang digunakan sebagai variabel pembeda rasio LDR bank umum yang terdaftar di BEI, terdiri atas :

$\mathrm{X} 1$ = ukuran atau total aktiva dari bank umum yang terdaftar di BEI periode 2010-2014

X2 = CAR dari bank umum yang terdaftar di BEI periode 2010-2014

X3 = NPL dari bank umum yang terdaftar di BEI periode 2010-2014

X4= ROAdari bank umum yang terdaftar di BEI periode 2010-2014 
X5 = ROE dari bank umum yang terdaftar di BEI periode 2010-2014

X6 = NWC dari bank umum yang terdaftar di BEI periode 2010-2014

Perhitungan Z cutting score akan dilakukan terhadap hasil dari simultancous estimation, yang akan menjadi patokan untuk klasifikasi bank-bank yang memiliki LDR tinggi dan LDR rendah. $Z$ cutting score ini akan dihitung secara manual dengan rumus sebagai berikut :

$\mathrm{Zcu}=\frac{\mathrm{Na} \mathrm{Zb}+\mathrm{Nb} \mathrm{Za}}{\mathrm{Na}+\mathrm{Nb}}$

Keterangan :

$\mathrm{Zcu}=$ Critical cutting score for unequal group size

$\mathrm{Na}=$ Jumlah bank yang tergolong Kelompok Bank dengan LDR tinggi (grup 1)

$\mathrm{Nb}$ = Jumlah bank yang tergolong Kelompok Bank dengan LDR rendah (grup2)

$\mathrm{Za}=$ Centroidgroup 1

$\mathrm{Zb}=$ Centroidgroup 2

\section{HASIL DAN PEMBAHASAN}

\section{Deskripsi Statistik}

Tabel 1.

Deskripsi Statistik Variabel Ukuran Bank, CAR, NPL, ROA, ROE, NWC Periode 2010-2014

\begin{tabular}{lcrrrr}
\hline Kelompok Bank & $\begin{array}{c}\text { Variabel } \\
\text { Independen }\end{array}$ & Mean & $\begin{array}{c}\text { Std. } \\
\text { Deviation }\end{array}$ & $\begin{array}{c}\text { Valid N (listwise) } \\
\text { Unweighted }\end{array}$ & Weighted \\
\hline LDR Tinggi (LDR & X1 & 10,6223 & 1,44741 & 13 & 13 \\
diatas rata-rata) & X2 & 17,6986 & 3,90823 & 13 & 13 \\
& X3 & 1,1200 & 0,59569 & 13 & 13 \\
& X4 & 2,0677 & 1,12554 & 13 & 13 \\
& X5 & 13,5254 & 6,45683 & 13 & 13 \\
LDR Rendah (LDR & X6 & 11,5162 & 3,39620 & 13 & 13 \\
dibawah rata-rata) & X2 & 10,6462 & 1,88068 & 13 & 13 \\
& X3 & 15,2923 & 1,88068 & 13 & 13 \\
& X4 & 1,55446 & 2,23858 & 13 & 13 \\
& X5 & 11,5623 & 19,1621 & 13 & 13 \\
& X6 & 10,3708 & 3,27720 & 13 & 13 \\
\hline
\end{tabular}

Sumber : Data diolah, 2017

Berdasarkan tabel 1.diketahui bahwa kelompok bank dengan LDR tinggi memiliki total aset lebih besar dibandingkan kelompok bank dengan LDR rendah. 
Kelompok bank dengan LDR tinggi juga menunjukan kecukupan modal yang lebih tinggi untuk memenuhi likuiditasnya. Kualitas penyaluran kredit kelompok bank dengan LDR tinggi lebih baik begitu juga dengan tingkat laba dari pengelolaan aset namun memiliki pengelolaan modal yang lebih rendah dibandingkan dengan kelompok bank dengan LDR rendah.

\section{Metode Simultancous Estimation}

1) Uji Statistik Wilk's Lamda atau F-test

Tabel 2.

Tests of Equality of Group Means

\begin{tabular}{cccccc}
\hline Variabel Pembeda & Wilks' Lambda & F & df1 & df2 & Sig. \\
\hline X1 & 1,000 & 0,001 & 1 & 24 & 0,971 \\
X2 & 0,862 & 3,854 & 1 & 24 & 0,061 \\
X3 & 0,867 & 3,678 & 1 & 24 & 0,067 \\
X4 & 0,978 & 0,545 & 1 & 24 & 0,467 \\
X5 & 0,995 & 0,123 & 1 & 24 & 0,729 \\
X6 & 0,873 & 3,493 & 1 & 24 & 0,074 \\
\hline
\end{tabular}

Sumber : Data diolah, 2017.

Tabel 2.menunjukkan angka Wilk's Lambda untuk variabel independen berkisar antara 0,862 sampai dengan 1,000. Uji hipotesis berdasarkan F-test adalah sebagai berikut:

a) Jika nilai Sig. > 0,1 maka variabel independen tidak secara signifikan dapat membedakan rata-rata rasio LDR bank.

b) Jika nilai Sig. $<0,1$ maka variabel independen secara signifikan dapat membedakan rata-rata rasio LDR bank.

Hasil uji hipotesis dengan menggunakan Wilk's Lamda dan F-test adalah sebagai berikut:

1) Hasil pengujian ukuran bank (X1) diperoleh nilai Wilk's Lambda1,000 dan angka Sig. 0,971>0,1. Hasil pengujian menunjukkanterdapat perbedaan ratarata yang tidak signifikan pada ukuran bank antara kelompok bank yang 
memiliki rata-rata rasio LDRtinggi dengan kelompok bank yang memiliki rata-rata rasio LDR rendah, sehingga ukuran banktidak dapat membedakan secara signifikan tingkat rasio LDR bank.

2) Hasil pengujian CAR (X2) diperoleh nilai Wilk's Lambda 0,862 dan angka Sig. $0,061<0,1$ yang menunjukkan terdapat perbedaan rata-rata yangsignifikan pada CAR antara kelompok bank yang memiliki rata-rata rasio LDRtinggi dengan kelompok bank yang memiliki rata-rata rasio LDR rendah, sehingga CARtidak dapat membedakan secara secara signifikan tingkat rasio LDR bank

3) Hasil pengujian NPL (X3) memiliki nilai Wilk's Lambda 0,867 dan angka Sig. $0,067<0,1$ menunjukkan terdapat perbedaan rata-rata yang signifikan pada NPL antara kelompok bank yang memiliki rata-rata rasio LDRtinggi dengan kelompok bank yang memiliki rata-rata rasio LDR rendah, sehingga NPL dapat membedakan secara secara signifikan tingkat rasio LDR bank.

4) Hasil pengujian rasio ROA (X4) diperoleh nilai Wilk's Lambda 0,978 dan angka Sig. 0,467> 0,1 yang menunjukkanterdapat perbedaan rata-rata yangtidak signifikan pada rasio ROA antara antara kelompok bank yang memiliki rata-rata rasio LDRtinggi dengan kelompok bank yang memiliki rata-rata rasio LDR rendah, sehingga rasio ROA tidak dapat membedakan secara secara signifikan tingkat rasio LDR bank

5) Hasil pengujian rasio ROE (X5) memiliki nilai Wilk's Lambda0,995 dan angka Sig. 0,729> 0,1 menunjukkan terdapat perbedaan rata-rata yang tidak signifikan pada rasio ROE antara antara kelompok bank yang memiliki rata- 
rata rasio LDRtinggi dengan kelompok bank yang memiliki rata-rata rasio LDR rendah, sehingga rasio ROE tidak dapat membedakan secara secara signifikan tingkat rasio LDR bank

6) Hasil pengujian variabel NWC (X6) memiliki nilai Wilk's Lambda 0,873 dan angka Sig. $0,074<0,1$ menunjukkan terdapat perbedaan rata-rata yang signifikan pada NWC antara antara kelompok bank yang memiliki rata-rata rasio LDRtinggi dengan kelompok bank yang memiliki rata-rata rasio LDR rendah, sehingga rasio $\mathrm{ROE}$ dapat membedakan secara secara signifikan tingkat rasio LDR bank.

2) Fungsi Diskriminan dengan Metode Simultances Estimation

Tabel 3.

Koefisien Fungsi Diskriminan yang distandardisasi dan yang Tidak Distandardisasi

\begin{tabular}{ccc}
\hline Variabel Pembeda & $\begin{array}{c}\text { Standardized Canonical Discriminant } \\
\text { Function }\end{array}$ & $\begin{array}{c}\text { Unstandardized Canonical } \\
\text { Discriminant Function }\end{array}$ \\
\hline X1 & $-0,318$ & $-0,190$ \\
X2 & $-0,526$ & $-0,168$ \\
X3 & 1,031 & 0,854 \\
X4 & $-1,000$ & $-0,564$ \\
X5 & 1,783 & 0,125 \\
X6 & 0,063 & 0,020 \\
\hline Constant & & 2,701 \\
\hline Sumber:
\end{tabular}

Sumber : Data diolah, 2017

Tabel 3.menunjukkan fungsi diskriminan dengan persamaan sebagai berikut:

a) Berdasarkan Standardized Canonical Discriminant Function (SCDF)

$Z=-0,318 \times 1-0,526 \times 2+1,031 \times 3-1,000 \times 4+1,783 \times 5+0,063 \times 6$

b) Berdasarkan Unstandardized Canonical Discriminant Function (UCDF)

$Z=-0,190-0,168 X 1+0,854 X 2-0,564 X 4+0,125 X 5+0,020 X 6$

Berdasarkan persamaan SCDF diketahui bahwa variabel-variabel yang berperan dalam membedakan rata-rata rasio LDR bank adalah semua rasio-rasio 
keuangan dan berdasarkan persamaan UCDF diketahui nilai-nilai diskriminan kelompok bank dengan rata-rata rasio LDR tinggi dan kelompok bank dengan rata-rata rasio LDR rendah .

Fungsi diskriminan yang terbentuk berguna untuk memprediksi apakah suatu bank termasuk kelompok bank dengan rata-rata rasio LDRtinggi atau kelompok bank dengan rata-rata rasio LDR rendah berdasarkan rasio keuangan bank yang meliputi total asetbank (X1), Capital Adequecy Ratio(X2), Non Perfoming Loans (X3), Return on Asset (X4), Return on Asset (X5), dan Net Working Capital (X6).

3) Uji Akurasi Ketepatan Fungsi Diskriminan

Nilai conanical correlation sebesar 0,522 bila dikuadratkan menjadi sebesar 0,2725 yang berarti keenam variabel independen secara bersama-sama mempengaruhi rasio LDRbank umumhanya sebesar 27,23\% sedangkan72,77\% dipengaruhi faktor lain diluar model misalnya faktor manajemen, regulator atau rasio keuangan lainnya yang tidak menjadi variabel independen dalam penelitian ini.

Tabel 4.

Tabel Analisa Eigenvalues

\begin{tabular}{ccccc}
\hline Function & Eigenvalue & \% of Variance & Cumulative \% & $\begin{array}{c}\text { Canonical } \\
\text { Correlation }\end{array}$ \\
\hline 1 & 0,374 & 100,0 & 100,0 & 0,522
\end{tabular}

Sumber : Data diolah, 2017

Tabel 5.menunjukkan angka chi-square sebesar 6,671 dan nilai sig. 0,352 atau diatas 0,1 , menunjukkan tingkat signifikansi yang rendah. Tingkat signifikansi yang rendah mencerminkan hampir tidak adanya perbedaan yang jelas 
antara kelompok bank yang memiliki rata-rata rasio LDR tinggi dengan rata-rata rasio LDR rendah.

Tabel 5.

Wilks' Lambda

\begin{tabular}{ccccc|}
\hline Test of Function(s) & Wilks' Lambda & Chi-square & Df & Sig. \\
\hline 1 & 0,728 & 6,671 & 6 & 0,352 \\
\hline
\end{tabular}

Sumber : Data diolah, 2017

4) Hasil Klasifikasi (Classification Result)

Tabel 6.

Hasil Klasifikasi Dua kelompok Bank Berdasarkan Nilai Z

\begin{tabular}{crrr}
\hline \multirow{2}{*}{ Kelompok Bank } & \multicolumn{2}{c}{ Prediksi Keanggotaan Kelompok } & \multirow{2}{*}{ Total } \\
\cline { 2 - 3 } & \multicolumn{2}{c}{ LDRTinggi } & \multicolumn{2}{c}{ LDR Rendah } & \\
\hline LDRTinggi & 9 & 4 & 13 \\
LDR Rendah & $(69,2 \%)$ & $(30,8 \%)$ & \multirow{2}{*}{13} \\
& 4 & 9 & \\
\hline
\end{tabular}

Sumber : Data diolah, 2017

Tabel 6.menunjukkanmenunjukkan bahwa pada data awal termasuk dalam kelompok bank dengan rata-rata rasio LDR tinggi(diatas rata-rata rasio LDR bank) sebanyak 13 bank. Berdasarkan klasifikasi fungsi diskriminan, yang tetap pada kelompok bank dengan rata-rata rasio LDR tinggi adalah 9 bank atau prosentase kasus diklasifikasikan secara benar sebesar 69,2\%. Sebanyak 4 bank yang pada data awal termasuk dalam kelompok bank dengan rata-rata rasio LDRtinggi, namun setelah klasifikasi fungsi diskriminan menjadi anggota kelompok bank dengan rata-rata rasio LDRrendah(dibawah rata-rata rasio LDR bank) atau terjadi kesalahan klasifikasi sebesar 30,8\%.

Ketepatan prediksi dari model diskriminan yang telah terbentuk adalah sebesar $69,2 \%$ yang mencerminkan model diskriminan yang terbentuk bisa digunakan untuk memprediksi pengelompokan bankmasuk sebagai kelompok 
bank dengan rata-rata rasio LDR tinggi (di atas rata-rata) atau kelompok bank dengan rata-rata rasio LDR rendah (di bawah rata-rata).

\section{5) Group Centroid (Rata-Rata Nilai Diskriminan)}

Hasil perhitungan rata-rata nilai diskriminan masing-masing kelompok rasio keuangan bank dalam fungsi diskriminan diperoleh nilai sebagai berikut :

a) Centroid untuk kelompok bank dengan rata-rata rasio LDR tinggi atau di atas rata-rata sebesar $-0,587$.

b) Centroid untuk kelompok bank dengan rata-rata rasio LDRrendah atau di bawah rata-rata sebesar 0,587

Batas nilai $\mathrm{Z}$ antara kelompok bank dengan rata-rata rasio LDR tinggi dan rata-rata rasio LDR rendah dengan menggunakan $\mathrm{Z}$ centroid adalah sebagai berikut :

$\mathrm{Z}$ cutting score $=\underline{(13)(-0,587)+(13)(0,587)}$

$13+13$

$$
=0
$$

Berdasarkan perhitungan $\mathrm{Z}$ cutting score di atas, diketahui hal-hal sebagai berikut:

1. Suatu bank dikategorikan sebagai kelompok bank dengan rata-rata rasio LDR tinggi (grup 1) jika memiliki Z cutting score di bawah 0 ( $\mathrm{Z}$ cutting score $<0)$.

2. Suatu bank dikategorikan sebagai kelompok bank dengan rata-rata rasio LDR rendah (grup 2) jika memiliki Z cutting score di atas 0 ( $\mathrm{Z}$ cutting score $>0$ ). 
Fungsi diskriminan yang telah terbentuk dan hasil perhitungan $\mathrm{Z}$ cutting score selanjutnya digunakan untuk mengklasifikasikan bank-bank ke dalam kelompok bank dengan rata-rata rasio LDR tinggi atau rendah.

Tabel 7.

Koefisien Fungsi Klasifikasi Masing-Masing Kelompok

\begin{tabular}{ccc}
$\begin{array}{c}\text { Variabel } \\
\text { Pembeda }\end{array}$ & $\begin{array}{c}\text { Rasio LDR tinggi (diatas rata-rata } \\
\text { rasio LDR bank) }\end{array}$ & $\begin{array}{c}\text { Rasio LDR rendah (dibawah rata- } \\
\text { rata rasio LDR bank) }\end{array}$ \\
\hline X1 & 9,502 & 9,279 \\
X2 & 4,460 & 4,462 \\
X3 & 4,878 & 5,881 \\
X4 & $-2,660$ & $-3,323$ \\
X5 & -0.072 & 0,074 \\
X6 & $-0,307$ & 0,283 \\
(Constant) & $-88,350$ & $-85,176$ \\
\hline
\end{tabular}

Sumber : Data diolah, 2017

Tabel 7.persamaan fungsi diskriminan untuk masing-masing kelompok, yaitu

1) Persamaan fungsi diskriminan untuk kelompok bank dengan rata-rata rasio

LDR tinggi atau diatas rata-rata adalah

$$
\begin{aligned}
Z= & -88,350+9,502 \times 1+4,460 \times 2+4,878 \times 3-2,660 \times 4-0,072 \times 5- \\
& 0,307 X 6
\end{aligned}
$$

2) Persamaan fungsi diskriminan untuk kelompok bank dengan rata-rata rasio

LDR rendah atau dibawah rata-rata adalah

$$
\begin{aligned}
& Z=-85,176+9,279 X 1+4,262 X 2+5,881 X 3-3,323 X 4+0,074 X 5- \\
& 0,283 X 6
\end{aligned}
$$

Variabel yang Dapat Membedakan Rasio Likuiditas Bank Umum yang Terdaftar di BEI periode 2010-2014

Hasil uji hipotesis dengan menggunakan Wilk's Lambda dan F-test dari 6 (enam) variabel independen dalam penelitian adalah sebagai berikut: 
1) Ukuran atau total aset bank umummemiliki nilai Wilk's Lambda1,000 dan angka Sig. 0,971>0,1 yang berarti ukuran atau total aset bank umumtidak dapat membedakan secara signifikan rata-rata rasio LDR bank pada kelompok bank dengan rata-rata rasioLDR tinggi dan rata-rata rasio LDR rendah. Tidak adanya perbedaan yang signifikan antara kelompok bank dengan rata-rata rasio LDR tinggi dan rata-rata rasio LDR rendah. Hasil penelitian ini tidak sejalan dengan penelitian Ahmed et al (2011), Anjum (2012), Ramzan (2014), Ghenimi (2015) dimana semua penelitian tersebut ukuran bank berpengaruh positif signifikan terhadap likuiditas. Penelitian ini sejalan dengan penelitian yang dilakukan oleh Asim (2012), Arif (2013), Azam et al (2013)dan Ogilo (2015), yang menghasilkan ukuran bank berhubungan negatif terhadap likuiditas di bank konvensional, sedangkan dalam penelitian Akhtar et al (2011) ukuran bank berpengaruh positif namun tidak signifikan terhadap likuiditas bank konvensional. Struktur aset sangat berpengaruh terhadap besarnya laba yang dihasilkan bank. Apabila porsi terbesar aset adalah piutang dari penyaluran kredit, maka piutang dari penyaluran kredit (kategori lancar atau performing loan ) akan meningkatkan pendapatan bunga (Wild, Subramanyam, dan Halsey : 2010). Apabila ternyata porsi kredit tidak lancar lebih besar, maka akan berpengaruh terhadap pendapatan bank yang nantinya menyebabkan penurunan modal sehingga setiap kenaikan aset atau total aset akan menyebabkan penurunanlikuiditas.Ukuran bank atau total aset tidak secara signifikan membedakan kedua kelompok bank, dapat dikatakan bahwa kelompok bank 
dengan rata-rata rasio LDR tinggi dan rendah memiliki rata-rata total aset yang relatif sama.

2) Capital Adequecy Ratio(CAR) memiliki nilai Wilk's Lambda0,862 dan angka Sig. 0,061 < 0,1, hasil penelitian ini menunjukanCAR dapat membedakan secara signifikan terhadap rata-rata rasio LDR pada kelompok bank dengan rata-rata rasio LDR tinggi dan rata-rata rasio LDR rendah. CAR berkontribusi positifterhadap rata-rata rasio LDR yang berarti peningkatan rasio CAR berdampak pada penurunan LDR bank. Penelitian Akhtar et al (2011) terhadap risiko likuiditas menghasilkan bahwa CAR berpengaruhsignifikan terhadap risiko likuiditas didukung juga dengan penelitian Ahmadet al (2010) dan Anamet al (2012). Kelompok bank dengan rata-rata rasio LDR tinggi (diatas rata-rata rasio LDR bank) memiliki rata-rata rasio CAR yang lebih tinggi dari kelompok bank dengan rata-rata rasio LDR rendah. Rata-rata rasio CAR pada kelompok bank dengan rata-rata rasio LDR tinggi berbeda dengan kelompok bank dengan rata-rata rasio LDR rendah. Hal ini menunjukkan bank-bank dalam kedua kelompok tersebut memiliki kemampuan yang baik dalam mengelola kecukupan dana untuk menanggung risiko dari seluruh aktiva produktif bank yang berisiko.

3) Non Performing Loan (NPL) merupakan salah satu rasio yang digunakan untuk melakukan analisis terhadap likuiditas bank. Berdasarkan hasil pengujian, NPL memiliki nilai Wilk's Lambda 0,867 dan angka Sig. 0,067< 0,1 yang menunjukkan Non Performing Loan dapat membedakan secara signifikan tingkat likuiditas bank. Rasio NPL dinilai memiliki dampak yang 
signifikan terhadap tingkat likuiditas bank. Hal tersebut didukung hasil penelitian oleh Ahmed et al (2011) dan Ghenimi (2015)yang menunjukan peningkatan rasio NPL berpengaruh negatif terhadap risiko likuiditas. Rasio NPL berkontribusi negatif terhadap likuiditas bank yang berarti semakin tinggi NPL maka akan menyebabkan likuiditas bank menurun. Rata-rata NPL untuk kelompok bank dengan rata-rata rasio LDR rendah (dibawah rata-rata rasio LDR bank) lebih tinggi dari kelompok bank dengan rata-rata rasio LDR tinggi (dibawah rata-rata rasio LDR bank). Hal tersebut berarti bank dengan LDR tinggi memiliki kinerja yang lebih baik dalam mengelola kualitas kreditnya dibandingkan bank dengan LDR rendah.

4) Rasio Return On Assets (ROA) memiliki nilai Wilk's Lambda0,978 dan angka Sig. 0,467> 0,1, yang berarti perbedaan ROA antara kelompok bank yang memiliki rata-rata rasio LDR tinggi dan kelompok bank yang memiliki rata-rata rasio LDR rendah tidak signifikan. Kemampuan bank-bank mengelola aktiva yang dimiliki untuk menghasilkan laba bersih baik pada kelompok bank yang masuk dalam kelompok bank dengan rata-rata rasio LDR tinggi dan kelompok bank dengan rata-rata rasio LDR rendah tidak berbeda signifikan. Bank Indonesia sendiri telah menetapkan rasio ROA untuk kategori bank sehat diatas 1,5\% sampai $2 \%$ dan kategori sehat diatas 2\%. Dari hasil penelitian rata-rata rasio ROA bank yang masuk dalam keompok bank dengan rata-rata rasio LDR tinggi 1,99\% dan bank yang masuk dalam kelompok bank dengan rata-rata rasio LDR rendah 1,59\%. Bank yang terdaftar di BEI tentunya akan menjaga kinerja mereka dengan 
baik agar dapat menjaga nilai saham mereka.Semakin tinggi rasio ROA sebuah bank menunjukan semakin efektif bank memanfaatkan aktiva untuk menghasilkan laba bersih setelah pajak. Rasio ROA yang tinggi mencerminkan kinerja bank yang baik dalam pengelolaan aktiva. Penelitian yang dilakukan oleh Akhtar et al (2011), Anam et al (2012), Ahmed et al (2013), Muharam et al (2013), Arif (2013) dan Iqbal (2012) menyatakan ROA berpengaruh positif terhadap likuiditas bank.

5) Return On Equtiy(ROE) merupakan rasio keuangan yang menunjukan posisi laba bersih bank yang tersedia bagi pemegang saham. Berdasarkan penelitian rasio ROE memiliki nilai Wilk's Lambda0,995 dan angka Sig. 0,729>0,1, yang menunjukkan perbedaan ROE antara kelompok bank yang memiliki rata-rata rasio LDR tinggi dan kelompok bank yang memiliki rata-rata rasio LDR rendah tidak signifikan. Kemampuan bank-bank mengelola Penelitian Akhtar et al (2011) menunjukan rasio ROE berpengaruh terhadap likuiditas bank, hal yang sama pada penelitian Anam et al (2012), Muharam et al (2013) dan Arif (2012) dan Zafar et al (2012). Semakin tinggi rasio ROE menunjukan semakin tinggi laba ditahan sebagai sumber likuiditas bank sehingga semakin likuid bank.

6) Net Working Capital (NWC) memiliki nilai Wilk's Lambda 0,873 dan angka Sig. $0,074<0,1$,yang berarti rasio NWC antara kelompok bank yang memiliki rata-rata rasio LDR tinggi berbeda signifikan dengan rasio NWC kelompok bank yang memiliki rata-rata rasio LDR rendah.Penelitian Akhtar et al (2011) menyebutkan NWC berpengaruh positif terhadap likuiditas bank, didukung 
juga dengan penelitian Arif (2013) dan Anam et al (2012). Rasio NWC tinggi maka dana yang dimiliki bank untuk kegiatan operasionalnya tinggi sehingga bank mampu membayar kewajiban segeranya sehingga semakin tinggi NWC menunjukan semakin tinggi pula likuiditas bank. Bank yang masuk dalam kelompok bank dengan rata-rata rasio LDR tinggi memiliki dana yang lebih tinggi untuk menjalankan kegiatan operasionalnya dibandingkan dengan bank yang masuk dalam kelompok bank dengan rata-rata rasio LDR rendah.

\section{SIMPULAN DAN SARAN}

Berdasarkan hasil penelitian dan pembahasan diperoleh simpulan, berdasarkan uji diskriminan dengan metode simultance menunjukan variabelCapital Adequecy Ratio (CAR), Non Perfoming Loans (NPL) dan Net Working Capital (NWC) yang dapat membedakan tingkat likuiditas bank umumyang terdaftar di BEI dengan variabel yang paling dominan dan signifikan dapat dipergunakan untuk membedakan tingkat likuiditas bank umum adalah variabel Capital Adequecy Ratio (CAR). Keenam variabel independen menunjukan hubungan yang lemah dalam menentukan perbedaan rasio LDR antara kedua kelompok bank sehingga ketiga variabel yang tidak signifikan dapat membedakan yakni ukuran bank, Return on Asset (ROA) dan Return on Asset (ROE) juga perlu mendapat perhatian bank. Fungsi diskriminan yang diperoleh dari analisis diskriminan dengan metode simultance menyatakan bahwa model diskriminan Unstandardized Canonical Discriminant Function (UCDF) dapat mengklasifikasikan dua kelompok bank umum berdasarkan nilai diskriminannya 
dengan tepat sebesar 69,2\% dari total sampel atau terjadi kesalahan klasifikasi sebesar $30,8 \%$.

Beberapa saran yang dapat diberikan antara lain, manajemen bank perlu memperhatikan kecukupan modal dan aset yang dimilikinya serta kualitas pemberian kredit yang ditunjukan melalui rasio Capital Adequecy Ratio (CAR),Non Performing Loan (NPL), dan Net Working Capital (NWC)mengingatketiga rasio keuangan tersebut yang paling tepat dan signifikan dapat dipergunakan untuk membedakan tingkat likuiditas bank umum, terutama kecukupan modal yang dihubungkan dengan bobot risiko aktiva yang dimiliki bank ditunjukan melalui rasio CAR yang menjadi variabel dominan yang membedakan tingkat likuiditas bank umum.

\section{IMPLIKASI PENELITIAN}

Implikasi dari penelitian ini menunjukkan bahwa hasil penelitian ini bisa memberikan bukti empiris bahwa model diskriminan yang dibentuk dari 6 (enam) rasio keuangan bank meliputi ukuran bank, Capital Adequcy Ratio (CAR), Return on Asset (ROA), Return on Equity (ROE), Non Performing Loan (NPL), dan Net Working Capital (NWC) secara bersama-sama dapat digunakan untuk memprediksi pengelompokan suatu bank masuk dalam kelompok bank dengan rasio LDR tinggi atau kelompok bank dengan rasio LDR rendah.

Implikasi dari penelitian ini juga menunjukkan bahwa 6 (enam) rasio keuangan bank meliputi ukuran bank, Capital Adequacy Ratio (CAR), Return on Asset (ROA), Return on Equity (ROE), Non Performing Loan (NPL), dan Net 
Working Capital (NWC) terdapat 3 (tiga) rasio keuangan yang paling tepat dan signifikan dapat digunakan sebagai pembeda dalam pengelompokan bank dengan rata-rata LDR tinggi dan bank dengan rata-rata LDR rendah, yakniCapital Adequecy Ratio (CAR), Non Performing Loan (NPL)dan Net Working Capital (NWC) dengan variabel yang dominan dapat membedakan adalah Capital Adequecy Ratio (CAR). Ketiga variabel tersebut perlu mendapat perhatian manajemen bank dalam mengelola operasionalnyadalam rangka menjaga tingkat likuiditas. Bank perlu memperhatikan kualitas kredit yang diberikan dan menjaga kecukupan modal serta aset untuk menjalankan aktivitas operasionalnya.

\section{REFERENSI}

Ahmed, Neveed.,et al. 2011. Risk Management Practices and Islamic Banks: An Empirical Investigation from Pakistan. Interdisciplinary Journal of Research in Business, 1(6), 50-57.

Ahmed Arif, Ahmed Nauman Anees. 2012. Liquidity risk and performance of banking system. Journal of Financial Regulation and Compliance, Vol. 20 Iss: 2 pp. $182-195$.

Ahmed et al. 2013. How Islamic Banks of Malaysia Managing Liquidity? An Emphasis on Confronting Economic Cycles.International Journal of Business and Social Science. Vol. 4 No. 7; July 2013

Akhtar, et al. 2011. Liquidity Risk Management: A Comparative Study Between Conventional and Islamic Bank of Pakistan. Interdisciplinary Journal of Research in Business, 1 (1), 35-44.

Altman, E.I. 1968. Discriminant Analysis and The Prediction of Corporate Bankcruptcy, Journal of Finance, September, 1968

Ameni Ghemini. 2015. Liquidity Risk Management : A Comparative Study between Islamic and Conventional Banks. Journal of Business Management and Economic ISSN 23-47-5471. 
Anjum Iqbal. 2012. Liquidity Risk Management : A Comparative Study between Conventional and Islamic Banks of Pakistan. Global Journal of Management and Business Research Volume 12 issue 5 version 1.0.

Arif Lukman Santoso et al. 2013. Analisis Faktor-faktor yang Mempengaruhi Likuiditas Perbankan di Indonesia. Jurnal Fakultas Ekonomi dan Bisnis Universitas Jendral Soedirman Vol.3 No. 1

Asim Abdullah \& Abdul Qayyum Khan. A Comparative Study Between Domestic and Foreign Banks in Pakistan. Journal of Managerial Science Volume IV Number 1.

Bank Indonesia 2011, Surat Edaran Bank Indonesia No 13/24/DPNP tanggal 25 Oktober 2011, Jakarta.

Brigham, Eugene F., Daves, Phillips R. 2007. Intermediate Financial Management, $9^{\text {th }}$ Edition. South Western Thomson Corporation, USA.

Brigham, Eugene F., Houston, Joel F. 2004. Fundamental of Financial Management, $10^{\text {th }}$ Edition. Ali Akbar Yulianto (Penerjemah). Dasar-Dasar Manajemen Keuangan.Jakarta : Salemba Empat.

Brigham, Eugene F., Daves, Phillips R. 2010. Intermediate Financial Management, $10^{\text {th }}$ Edition. South Western Thomson Corporation, USA.

Bunda, I. and J. B. Desquilbet, 2008. The Bank Liquidity Smile Across Exchange Rate Regimes. International Economic Journal, 22(3), 361-386. ISSN 1743-517X.

Consultative Paper Bank Indonesia tahun 2009.

Dahlan Siamat.2009, Manajemen Lembaga Keuangan Edisi Kelima. Jakarta : LPFE.UI.

Diamond, D.W. (2007), "Banks and Liquidity Creation: A Simple Exposition of the Diamond-Dybvig Model", Economic Quarterly_Volume 93, Number 2-Spring 2007-Pages 189-200

Fahmi, Irham.2011. Analisis Laporan Keuangan, ALFABETA, Bandung.

Fredrick Ogilo, Leonard Oscar Mugeyah, 2015, Determinants of Liquidity Risk of Commercial Banks in Kenya, The International Journal of Business \& Management Vol 3 Issue 9. 
Gantiah Wuryandani, Ramlan Ginting, Dudy Iskandar, Zulkarnain Sitompul, 2014, Pengelolaan Dana dan Likuiditas Bank, Buletin Ekonomi Moneter dan Perbankan.

Goodhart, C. (2008), "Liquidity risk management", Financial Stability Review, Vol. 11 No. 6

Jenkinson, N.2008. Strengthening Regimes For Controlling Liquidity Risk. Euro Money Conference on Liquidity and Funding Risk Management,6, 9-14.

Kasmir. 2013. Dasar-dasar Perbankan. Rajawali Press : Jakarta.

Kodifikasi Kesehatan Bank, Bank Indonesia, 2013

Lukman Dendawijaya, 2009. Manajemen Perbankan Edisi Kedua. Jakarta : Ghalia Indonesia.

Latumaerissa, Julius R,. 2014. Manajemen Bank Umum. Mitra Wacana Media: Jakarta.

Muhammad Ramzan, 2014. Liquidity Risk Management in Islamic Bank : A Study of Islamic Banks of Pakistan, Interdisciplinary Journal of Contemporary Research in Business Vol 5 No 12.

Naveed et al, 2011. Liquidity Risk and Islamic Banks: Evidence from Pakistan, Interdisciplinary Journal of Research in Business Vol. 1, Issue. 9, (pp.99102) September, October, 2011.

Peraturan Bank Indonesia no 15/7/PBI/2013 mengenai perubahan atas PBI no 12/19/PBI/2010.

Santoso, Singgih. 2015. Menguasai Statistik Multivariat : Konsep Dasar dan Aplikasi dengan SPSS. Jakarta : PT Elex Media Komputindo

Shen, C.H., Chen, Y.K., Kao,L.F., Yeh, C.Y. 2009. Bank Liquidity Risk and Performance.

Sayedul Anam et al. 2012. Liquidity Risk Management : AComparative Study of Islamic Banks of Bangladesh, Research Journal of Economics and Business ICT ISSN 2045-3345.

Syafitri, Erlina Dwi.2011. Pengaruh CAR, NPL, LDR, NIM, dan Size terhadap Risiko Bisnis Bank. Skripsi Universitas Diponegoro. http://eprints.undip.ac.id/. 
Undang-undang Republik Indonesia Nomor 10 Tahun 1998. Tentang Perubahan Undang-undang Nomor 7 Tahun 1992 tentang Perbankan.

VODOVÁ, P. 2010. Determinant of Commercial bank's Liquidity in Poland, Proceedings of $30^{\text {th }}$ International Conference Mathematical Methods in Economics.

Veithzal Rivai dan Andria Permata Veithzal. 2007. Credit Management Handbook. Jakarta: RajaGrafindo Persada.

Wild, J.J, Subramanyam, K.R, dan Hasley, R.F, 2010.Analisa Laporan Keuangan. Edisi 10. Salemba Empat : Jakarta. 